\title{
Protecting Traditional Knowledge Related to Biological Resources: Is Scientific Research Going to Become More Bureaucratized?
}

\author{
Prashant Reddy and Malathi Lakshmikumaran \\ Lakshmikumaran \& Sridharan, New Delhi, 110029, India \\ Correspondence: malathi@lakshmisri.com
}

For the past several decades, there has been a world debate on the need for protecting traditional knowledge. A global treaty appears to be a distant reality. Of more immediate concern are the steps taken by the global community to protect access to biological resources in the name of protecting traditional knowledge. The Indian experience with implementing the Convention on Biological Diversity has created substantial legal uncertainty in collaborative scientific research between Indians and foreigners apart from bureaucratizing the entire process of scientific research, especially with regard to filing of applications for intellectual property rights. The issue therefore is whether the world needs to better balance the needs of the scientific community with the rights of those who have access to traditional knowledge.

\begin{abstract}
$A$ mong all of the polarizing debates on intelAlectual property (IP) regimes around the world today, the traditional knowledge (TK) debate has not received as much attention as the patentability of genes and diagnostics. Not only does the TK debate feature an interesting role reversal between developing and developed countries, it also raises fundamental questions about equity, property, and justice.

In the TK debate, it is the developing countries that are traditionally the fiercest critics of an exclusionary IP regime and that are seeking to create new property rights in the domain of TK. These countries, like India, argue that indigenous communities should be entitled to the
\end{abstract}

protection of their TK through a global treaty regime just as modern industrial IP is protected through treaties such as the Agreement on TradeRelated Aspects of Intellectual Property Rights (TRIPs).

On the other hand, the corporations of the developed world along with their governments, which have traditionally lobbied for greater IP rights through agreements like TRIPs, are possibly the greatest opponents of the demands made by developing countries because of fears that the proposed measures to protect TK would create an unpredictable regime that would kill innovation through trade barriers. Although there has been some consensus on this point

Editors: Salim Mamajiwalla and Rochelle Seide

Additional Perspectives on Intellectual Property in Molecular Medicine available at www.perspectivesinmedicine.org

Copyright (C) 2015 Cold Spring Harbor Laboratory Press; all rights reserved; doi: 10.1101/cshperspect.a020974

Cite this article as Cold Spring Harb Perspect Med 2015;5:a020974 
P. Reddy and M. Lakshmikumaran

in recent years between opposing lobbies, with jurisdictions like the European Union (EU) agreeing to side with the developing countries, a global treaty is still a distant dream despite more than a decade of global negotiations.

The question that should trouble the scientific community is whether the impasse in negotiating a global consensus on TK protection and the measures already negotiated under the umbrella of the Convention on Biodiversity (CBD) will complicate and bureaucratize transboundary research into areas involving biological material that may or may not be related to TK. Judging by the Indian experience over the last decade, where the transfer of biological material has been heavily regulated and in one instance criminally prosecuted, the global scientific community should certainly be concerned about a similar framework being instituted worldwide.

This article attempts to get to the very root of the TK debate by examining the jurisprudential, political, and economic aspects of the debate and raising issues that need to be debated by the community of scientists in industry and academia.

\section{THE CONTOURS OF TK: SPOTTING THE ISSUES}

TK can be divided into two broad categories. The first category, traditional cultural expressions (TCEs), covers artistic works, musical works, symbols, etc., of indigenous people. The second category is biological resource-related TK, which covers areas like herbal medicine and traditional remedies that have been created through the ability of indigenous communities to identify the medicinal properties of various biological resources within their geographical boundaries. Both categories pose their own unique challenges to the present legal regime.

TCEs can be accommodated, to an extent, within conventional legal regimes such as copyright law, trademark law, and geographical indications law, which protects well-known names that are the result of community efforts. Some well-known examples are Darjeeling tea and champagne. In India, geographical indica- tions law has been used extensively to protect TCEs. Some countries have enacted sui generis laws to protect just TCEs, especially countries with large indigenous populations. For example, the United States enacted the Indian Arts and Craft Arts Act of 1990 for the specific purpose of protecting the arts and crafts of Native Indian tribes.

India, which has assumed the leadership mantle among developing countries in TK negotiations, has yet to pass an equivalent sui generis law to protect TCEs that cannot otherwise be protected under the conventional IP regimes.

The second category (i.e., TK associated with biological resources), which is the focus of this review, is significantly more complicated. The typical targets for protection in this class are herbal remedies or plant-based medicines that have been used by a group of indigenous people for several generations.

An example of such a case in India is that of the arogyapacha plant (Trichopus zeylanicus subsp. travancoricus), whose properties were identified by the Kani tribe located in Kerala, India. According to a World Intellectual Property Organization (WIPO) report, ${ }^{1}$ during an expedition in 1987 in which the Kani were guiding government scientists belonging to the Tropical Botanical Garden and Research Institute (TBGRI), the scientists noticed that the Kani were not getting tired despite significant physical exertion and were constantly chewing on some black berries. On inquiring with the Kani, the scientists were given a few of the black berries to chew on, after which they felt revitalized. The scientists realized that the berries had properties that relieve fatigue (Chaturvedi 2009).

According to the WIPO report, although the tribe had its own customs governing the sharing of knowledge pertaining to its traditional remedies, under pressure from the scientists, they identified the arogyapacha plant as the source of the berries. The Indian scientists from the TBGRI took back with them samples of this

${ }^{1}$ WIPO case study: "Using traditional knowledge to revive the body and a community." http://www.wipo.int/ip advantage/en/details.jsp?id $=2599$. 
plant, and after 8 years of research they managed to isolate 12 active chemical compounds that had many more beneficial properties than what was initially known. Incidentally, during their research the scientists discovered that the leaves were more beneficial than the berries (Chaturvedi 2009).

Subsequently, in 1994, the scientists at the TBGRI filed for patents and licensed the same to an Indian pharmaceutical company for U.S. $\$ 50,000$ plus $2 \%$ royalties on all sales. In 1997 the TBGRI assisted the Kani in setting up a trust to document their TK (they had knowledge of other plants apart from arogyapacha) and enter into benefit-sharing agreements. Adult Kanis were in control of the trust. In a couple of years, according to the WIPO report, the Kani reportedly received the first payment of U.S. $\$ 12,500$.

The Kani-arogyapacha story is an interesting example of how TK can be commercialized to the benefit of all the parties involved. It also raises several issues that provide the framework for the discussion that follows in this work. These issues are as follows:

1. Should the scientists at the TBGRI have secured informed consent from the Kani before researching the arogyapacha plant and sharing the results because it was the Kani who had identified to the TBGRI the properties of the berries and the arogyapacha plant as the source of the berries themselves?

2. Who deserved to benefit from the commercialization of arogyapacha? Was it the Kani, who had initially identified the beneficial properties, or should it have been the scientists at the TBGRI who spent 8 years isolating the active compounds, or should it have been the company that took on the risk of investing in the manufacturing and marketing of the product?

3. Ideally, all three parties (the tribe, the scientists, and the company) who contributed to the process should benefit from the profits. But how do you decide how profits should be shared? The key to any fair negotiation is for all parties to the negotiation to have the right to refuse the deal. The scientists and the
Traditional Knowledge and Biological Resources

company can walk away from the deal if they do not like the terms, but do the Kani have any power to deny a deal when they do not own the biological material and when the biological material is sourced from a plant grown on government land?

4. What if the Kani denied permission for commercialization of the TGBRI's product? Should the TBGRI have walked away or should it have gone ahead by itself?

5. For how long should the company and the TBGRI be required to pay royalties to the Kani? Should the royalties be payable in perpetuity? Patents, after all, exist only for 20 years.

6. What if there is a disagreement within the Kani on whether to share knowledge with the TBGRI, or alternatively, what if there is a dispute within the Kani on how to use the royalties? Should the law respect the internal dispute mechanism of the tribe or should the Kani be subjected to normal civil procedure?

The issues posed above are complex and raise several moral, ethical, and legal questions. Keeping these issues in mind, we discuss below the dilemma in creating a legal framework to protect TK.

\section{THE DILEMMAS OF PROTECTING TK: IS THERE A CASE TO PROTECT TK AS PROPERTY?}

While creating any new system of property rights that is exclusionary in nature, it is necessary to question the basis of such a property right.

Intellectual property rights, like real property rights, can be justified through a variety of legal theories. Two of the most popular legal theories used to justify IP rights are (1) the natural rights theory and (2) the utilitarian theory. The issue is whether any of these theories can justify a system to protect TK.

The natural rights theory of property argues that a person is born into society with some natural or fundamental rights. Among these natural rights are the rights to life, liberty, and 
property. The natural rights theory of property, which is also called the labor theory, allows a person to claim as his property anything that is created by the mixing of his labor with "commonly held" resources. In the context of IP rights, this would mean that every time a person uses a commonly spoken language to create a poem or uses a known concept to create an invention, she would own the resulting poem or invention (Merges 2011).

The issue at question in this discussion is whether or not TK can be protected through a natural rights theory. Most of TK, as is commonly understood, especially TK related to biological resources, is handed down from generation to generation. Should descendants of persons who originally had access to TK have the same right to exclusively access such TK as their ancestors despite not having contributed anything to the creation of such TK? Would such a claim have a strong moral basis (Munzer and Raustiala 2009)?

The utilitarian theory allows for the creation of property rights only to the extent that such rights would benefit society as a whole. Thus, if the creation of a system of copyright law would create an incentive for people to create music and literature, the utilitarianism system would allow such a system to function. A key feature of the utilitarian model is to provide for such property rights only to the extent that it is required to incentivize the creation of new property. Therefore, in the context of IP, a utilitarian right would specify fixed time periods for copyrights and patents (Merges 2011).

Can the protection of TK be justified under a utilitarian model? The answer would once again depend on the type of TK in question. If it was static TK that was discovered generations ago, it would be difficult to justify its protection under the utilitarian model because such protection does not lead to any greater benefits for society, but if it was dynamic TK, which is constantly being innovated on, it would be worthy of protection under such a system (Munzer and Raustiala 2009).

However, the most fundamental roadblock to protecting $\mathrm{TK}$ as property is the fact that most indigenous people who have access to TK may not conceive of property and ownership in the same manner as is understood in capitalist societies (Mara 2011). How then should the international community justify the protection of TK within a system of conventional property rights?

These are complicated issues on which WIPO, through its intergovernmental committee, has debated considerably, but a conclusive, convincing answer is still far away (Gupta 2004).

\section{THE NORTH-SOUTH DEBATE ON TK AND IP}

The debate on TK so far has been a debate between the developed countries and developing countries that are considered to be rich in TK. The debate is on two points: (1) positive protection and (2) defensive protection (Munzer and Raustiala 2009). Both these debates are discussed below.

\section{Positive Protection}

This form of protection requires the law to provide those with access to TK exclusive rights over the use of such TK, which can then be enforced against third parties. Perhaps the only example of such TK-related protection in an international treaty today is the CBD.

The CBD reversed a previously well-accepted norm of international law that considered all biological resources to be the "common heritage of mankind," under which theory biological resources could be transferred freely over international borders without any restrictions.

However, under the CBD, each country could exercise national sovereignty over biological resources contained within its national boundaries. This recognition of sovereignty by the CBD means that each nation can now control the manner in which its biological resources are used for research and commercialization.

One of the reasons for granting nations sovereignty over their biological resources was the fact that developing countries were becoming increasingly aware that the developed world was developing products and inventions based on biological resources derived from resourcerich developing countries and subsequently 
selling them for significant monetary gains. An added concern was that the TK owned by indigenous groups in developing countries was likely being exploited by the developed world without any sharing of benefits with the indigenous people who had identified the potential of the biological resources. By protecting the TK owned by indigenous people, the CBD hoped to incentivize them to maintain the biological resources from which they derived their TK.

In this backdrop, the international community started negotiations on a new protocol to guide countries on "access and benefit sharing" (ABS) of results from biological resources. This protocol, which was finalized on October 29, 2010, in Nagoya, Japan, was thereafter called the Nagoya Protocol on Access to Genetic Resources and the Fair and Equitable Sharing of Benefits Arising from Their Utilization (the Protocol). It is yet to be ratified by most countries. As suggested by its name, the Protocol creates an international standard for regulating the manner in which countries may access biological resources of another country, along with the fair and equitable sharing of benefits that may arise from the use of such biological material with persons who have identified TK that is related to the biological resources in question.

The Protocol has, however, been criticized for failing in its aim to create a predictable and transparent regime for sharing of biological resources. The fear among policymakers and scientists is that the Protocol, like its parent Convention, has the potential to significantly complicate and bureaucratize scientific research because it neither defines the requirements for access to biological resources nor sets standards for defining fair and equitable benefit sharing.

As pointed out earlier in this review, in context of the example of the Kani tribe, "benefit sharing" can be a complicated concept, and the lack of an international consensus on this aspect can derail attempts to share biological resources across borders.

\section{Defensive Protection}

This is a negative form of protection that aims to prevent the patenting of TK.
Traditional Knowledge and Biological Resources

\section{Creation of the Traditional Knowledge Digital Library (TKDL)}

Countries like India have placed considerable emphasis on defensive patent protection measures because of specific incidents in the 1990s when TK that was well known in India, such as the properties of turmeric, was patented in the United States. Although there was no direct evidence of the patent causing economic harm to Indians, the Indian government appeared to have taken the incident as a slight to national pride. The incident of the turmeric patenting in the United States was accompanied by other cases of basmati- and neem-related patents in both the United States and the EU. The ensuing public outrage in India led to the government of India setting up the TKDL. The TKDL, which has been compiled through the translation and digitization of Indian books on TK, is a confidential database. Patent offices in the United States, EU, and Japan have been granted access to this database by India for the express purpose of weeding out patent applications based on Indian TK.

\section{Enactment of Section 3(p)}

In addition to the TKDL, the Patents (Amendment) Act, 2002 also introduced into Indian patent law Section 3(p), which prohibits the patenting of traditional knowledge. Specifically, the provision bars the patenting of "traditional knowledge" or the "aggregation or duplication of known properties of traditionally known component or components." The provision reads as follows:

Section 3: What are not inventions

(p) an invention which in effect, is traditional knowledge or which is an aggregation or duplication of known properties of traditionally

known component or components.

This provision was more a result of politics because the existing bar in Indian law against inventions that are not novel or inventive would have in any case prohibited the patenting of TK. Accordingly, there was thus no need for a specific provision to prohibit the patenting of TK. However, after the outrage in India against the 
patenting of basmati, neem, and turmeric in the United States, the enactment of Section 3(p) became a political device aimed at reassuring Indians that TK would not be patented in India.

In 2013 the Controller General of Patents, Designs \& Trademarks released a set of "Guidelines for Processing of Patent Applications Relating to Traditional Knowledge and Biological Material." These guidelines substantially raise the bar to patentability for inventions related to TK. The research community and patent lawyers have expressed concerns that these guidelines are unreasonable and are prohibiting the patenting of genuine inventions.

For example, Guiding Principle 1 states, "If the subject-matter as claimed relates to extracts/ alkaloids and/or isolation of active ingredients of plants, which are naturally/inherently present in plants, such claims cannot be considered as novel and/or inventive when use of such plants is pre-known as part of teachings of Traditional Knowledge." This is an extremely high barrier to patentability. Identifying, isolating, and purifying an active compound from a plant known to demonstrate certain properties can take significant amounts of time, skill, and investment. Such innovation deserves to be rewarded with a patent. The five other guiding principles mentioned by the Indian Patent Office similarly raise the bar to patentability by presuming certain combinations or uses from TK to be barred by Section 3(p) or are presumed to be obvious.

Over the last couple of years, the TKDL, which is administered by the Council for Scientific \& Industrial Research, has actively started filing pre-grant oppositions to patent applications on the grounds of Section 3(p). With the passing of time, as more patent applications are dismissed and appealed, the law on patenting related to TK will slowly evolve to provide applicants with a better understanding of the boundaries of patenting TK-related inventions.

\section{Mandatory Disclosure of Geographical Origin of Biological Material}

A second limb of defensive protection demanded by developing countries like India is for a mandatory disclosure, in the specification of the patent application, of the origin of biological material that was used in the invention being claimed in the patent application. The intention behind this demand is to give more teeth to an international enforcement regime under the CBD, which seeks to regulate the international transfer of genetic material (Carr 2008). A working example of this demand is as follows: If Company A files a patent application in Country B on the basis of research conducted on biological resources sourced from India, it would have to disclose in its patent application filed in Country B that the material has been sourced from India, failing which it could be revoked.

This demand by India and other developing countries has led to quite a stir in the international community, with several countries like the United States that are yet to ratify the CBD and do not recognize national sovereignty of countries over biological material. The United States argues that patent law and its associated treaties like TRIPs should not be used to implement issues pertaining to the $\mathrm{CBD}$ and is unlikely to accede to such a demand (Laurie 2005). Countries like India have already enacted amendments requiring disclosure of geographical origin of biological material in patent applications.

\section{ENACTMENT OF THE BIOLOGICAL DIVERSITY ACT, 2002: THE NATIONALIZATION OF BIOLOGICAL RESOURCES IN INDIA}

In 2002, about 8 years after India became a signatory to the $\mathrm{CBD}$, the Indian Parliament enacted the Biological Diversity Act, 2002 (BD Act), implementing as national law the provisions of the CBD. A key focus of this legislation as outlined in the "aims and objectives" of the legislation was to ensure the "fair and equitable sharing of the benefits arising out of the use of biological resources" (Gopalakrishnan 2002).

In a manner of speaking, the legislation nationalizes India's biological resources because the legislation in effect proclaims the sovereign- 
ty of the Indian state over all biological resources located within its territory. In doing so, India has reversed the fundamental principle of how natural resources were considered to be the common heritage of all mankind, without recognition of international boundaries. The reversal appears to have been fueled by a presumption that India had more to lose than gain under a legal regime that allows for the free trade of biological resources (Prathapan and Rajan 2011). This presumption, however, may not be entirely true, as India has benefited considerably through the free trade of biological resources. India's Green Revolution, in the 1960s, which ensured food security, was fueled by Norman Borlaug's hybrid variety of wheat, which was of foreign origin. Similarly, other food crops that are staples of the Indian diet, such as potato, tomato, and peas, are not of Indian origin.

Subsequent to the enactment of the BD Act, foreigners now need permission from the $\mathrm{Na}$ tional Biodiversity Authority (NBA) before accessing any biological resources located within India for the purpose of "research" or "commercial utilization" or "bio-survey" or "bio-utilization." On the other hand, Indians can access any biological resources located within India after a mere intimation to the State Biodiversity Board. However, the result of any research by Indians on such biological material cannot be transferred to foreigners without prior approval of the NBA.

The fact that Indians are allowed to access such biological resources without any preconditions presupposes that Indians are going to be fair and just in their dealing with their fellow Indians who may own valuable TK pertaining to biological resources. This crucial distinction in the permission required by Indians and foreigners betrays the protectionist, nationalist intent of the Indian legislation.

The legislation also prohibits any person, whether Indian or foreign, from applying for any IP rights "for any invention based on any research or information on a biological resource obtained from India without obtaining the previous approval of the NBA before making such application." While granting approval for
Traditional Knowledge and Biological Resources

the filing of such IP rights, the NBA has been given the power to "impose benefit sharing fee or royalty or both or impose conditions including the sharing of financial benefits arising out of the commercial utilization of such rights." These conditions may be imposed regardless of whether or not there is TK associated with such biological resources.

Given the framework imposed by the $\mathrm{BD}$ Act, it would not be an exaggeration to say that the Indian legislation in effect "nationalizes" biological resources and knowledge related to those biological resources, including TK held by indigenous people, because it is only bureaucrats sitting in the NBA who can decide the terms and conditions of benefit sharing. There is a gratuitous provision in the legislation that requires the NBA to ensure that "equitable benefit sharing" takes place on "mutually agreed terms and conditions between the person applying for such approval, local bodies concerned and the benefit claimers." But how can benefit claimers enter into a mutually beneficial deal when it is the NBA and not the benefit claimers who have the final say on how the resources are accessed (Gopalakrishnan 2002)?

Perhaps the most troubling aspect of the BD Act is that it does not provide for any statutory guidance on the issue of "equitable benefit sharing." This is a complicated issue. Take, for example, the Kani tribe. What percentage of the royalties would be deemed fair and equitable for the Kani's TK pertaining to the arogyapacha plant? How could the Kani have reached a "mutually" beneficial deal when they did not have the power to walk out of a deal that was not in their interests?

In 2010 the Indian government's auditor, the Comptroller and Auditor General of India, criticized the government of India for failing to notify ${ }^{2}$ guidelines on access to biodiversity, transfer of results of research and IP, etc., despite 6 years having passed since the BD Act had been notified into law (Comptroller and Audi-

\footnotetext{
${ }^{2}$ Under Indian law, the guidelines have to be "notified" to have force in India.
} 
tor General, Republic of India 2010). In the same year, the NBA invited the public to comment on drafts on ABS guidelines, a sui generis law (The Protection, Conservation and Effective Management of Traditional Knowledge Relating to Biological Diversity Rules, 2009) for protecting TK related to biological resources and potential amendments to the BD Act. For unknown reasons, none of the guidelines or amendments were finalized by the NBA. In 2013 the NBA once again invited public comments on draft ABS guidelines. These guidelines have yet to be finalized.

The fact that a country like India, which has been one of the most vocal supporters of the Nagoya Protocol and the CBD, has found it difficult to notify ABS guidelines 2 decades after signing the $\mathrm{CBD}$ is perhaps an indication that the CBD and Nagoya Protocol need to be revisited.

Given the Indian experience so far, the international community needs to question whether the IP rights framework is the best way to protect TK related to biological resources.

\section{IMPLEMENTATION OF THE BD ACT: THE BUREAUCRATIZATION OF BIOLOGICAL RESOURCES-RELATED SCIENTIFIC RESEARCH IN INDIA}

One of the fears expressed by the critics of the $\mathrm{CBD}$ is that the regime proposed by it would lead to an excessive bureaucratization of scientific research. These fears have come true to an extent in India.

In the last few years, ever since the NBA started enforcing the BD Act, scientific research projects by foreigners (including Indian companies with foreign holding) or in collaboration with foreigners and the subsequent protection of IP rights by both Indians and foreigners have become more bureaucratic, as prior approvals are required from the NBA at every stage. The necessity of prior approvals requires institutions to divert more resources to legal advice followed by a long wait for the NBA to grant approvals. The fact that the NBA has not notified the ABS guidelines adds to the uncertainty, complexity, and delays in the entire process (Prathapan and Rajan 2011).

In addition, the Indian Patent Office has also started objecting to patent applications for inventions related to biological resources on the grounds that prior NBA approval has not been sought by the applicant before the grant of patent applications. The cumulative effect of such regulatory frameworks is greater compliance costs and longer delays in conducting scientific research and commercialization of the same.

The general all-around complaint against the NBA has been that it is unpredictable and slow in granting approvals, resulting in delays in scientific research (Prathapan and Rajan 2011).

One particular case that warrants a more detailed explanation is the case of a scientific collaboration between the University of Agricultural Sciences (UAS), which is an India-based government university; the U.S. Agency for International Development (USAID); Cornell University; and Mahyco, an Indian seed company with foreign shareholding. USAID and Cornell were involved in the project through a third party, Sathguru Management Consultants.

Under the BD Act, a joint collaborative research project involving transfer of biological resources or information relating thereto between government-sponsored institutions of India and such institutions in other countries does not require prior approval from the NBA provided that such research projects conform to guidelines issued by the Central Government.

In the present case, the research project being undertaken by UAS was the result of a bilateral agreement between the governments of India and the United States to infuse more advanced technology into Indian agriculture to spur a gene revolution. This was supposed to be done through a public-private partnership, in which Cornell University, funded by USAID along with Mahyco, was supposed to help UAS, which was in turn funded by the Department of Biotechnology of the government of India, to develop genetically modified Bt brinjal. In this case UAS had allegedly failed to have the project approved by the government of India's Ministry of Environment and Forests. This failure, according to a green nongovernmental organiza- 
tion, was in breach of the BD Act. On a petition by the nongovernmental organization, the NBA initiated the criminal prosecution of the academics at UAS who had signed the tripartite agreement with Mahyco and USAID.

The case is still under prosecution, and a conviction could result in a criminal term of 5 years. This case highlights the penal provisions of Indian law on this issue. Criminal prosecutions of this nature can have a chilling effect on research institutions across the country. Independent of this prosecution, the sheer amount of regulation under the present legal regime has led to an excessive bureaucratization, which in itself is leading to a delay in finalizing funding for completion of research projects.

Even for India-based research projects without any foreign involvement, the fact that the NBA has a say in benefit sharing at the stage of filing a patent application leads to great uncertainty and, in the absence of any guidelines, makes it difficult to commercialize any research.

\section{CONCLUDING REMARKS-BALANCING REGULATION WITH THE NEED FOR INNOVATION}

As is obvious from this review, the protection of TK related to biological resources is a complicated subject. While there is certainly a case for rewarding communities that own valuable TK related to biological resources, there is also a need to ask whether IP rights is the most appropriate legal framework to recognize such rights. More importantly, it is necessary to balance such protection of knowledge from the past with the need to create new knowledge for the future.

Even the most vocal supporters of an international regime to protect such TK, like India, are finding it difficult to enact even a domestic legal regime on this point. The measures enacted so far in countries like India, like the BD Act, have created a maze of regulations that are lacking in predictability. The last two attempts to enact $A B S$ guidelines have not gone beyond the stage of inviting comments on drafts.

Far from protecting communities with access to $\mathrm{TK}$, the Indian measures under the $\mathrm{BD}$
Traditional Knowledge and Biological Resources

Act have ended up complicating collaborative research projects between Indians and foreigners and delaying the transfer of research results to foreign parties. The legislation also causes a delay in applications for patents and other IP rights arising out of research into biological resources. In other words, the current Indian legal framework to protect TK related to biological resources needs a serious rethink. A rational and predictable framework appears to be a distant dream as long as policymakers fail to identify a strong theoretical foundation for the protection of such rights.

Countries like India and Brazil, which have been declared mega-biodiversity hot spots, have a lot to offer to the world through their biological resources. Legislations like the BD Act will end up having a chilling effect on research in these countries. The aim of any new policy initiative in this regard should be to balance the need for future research with the need to protect communities with access to TK. The barriers to sharing biological resources across international boundaries must be simplified for the sake of scientific research and mankind.

\section{REFERENCES}

Carr J. 2008. Agreements that divide: TRIPs v. CBD and proposals for mandatory disclosure of source and origin of genetic resources in patent applications. J Transnational Law Policy 18: 131.

Chaturvedi S. 2009. The role of scientists and the state in benefit sharing: Comparing institutional support for the San and Kani. In Indigenous peoples, consent and benefitsharing: Lessons from the San-Hoodia case (ed. Wynberg R, et al.), pp. 261-270. Springer, Dordrecht, The Netherlands.

Comptroller and Auditor General, Republic of India. 2010. Environmental Audit Report, Report No. 17 of 2010/2011. www.cag.gov.in/html/reports/civil/2010-11 _17SD-_CA-Environment/exe-sum.pdf.

Gopalakrishnan NS. 2002. Protection of traditional knowledge: The need for a sui generis law in India. J World Intell Prop 5: 725-742.

Gupta AK. 2004. WIPO-UNEP study on the role of intellectual property rights in the sharing of benefits arising from the use of biological resources and traditional knowledge. World Intellectual Property Organization, Geneva, Switzerland. www.wipo.int/edocs/pubdocs/en /tk/769/wipo_pub_769.pdf.

Gupta AK. 2005. CBD and TRIPS: Empowering knowledge rich, economically poor people through IPR reforms. Presented at the National Seminar on TRIPS-CBD and 
P. Reddy and M. Lakshmikumaran

Subsidy Issues at the WTO on August 25, 2005, New Delhi, India. www.sristi.org/mdpipr2006/day1/CBD_ TRIPS_24\%20Aug\%2005.pdf.

Laurie G. 2005. Should there be an obligation of disclosure of origin of genetic resources in patent applications? - Learning lessons from developing countries. SCRIPTed 2: 265272. www.law.ed.ac.uk/ahrc/script-ed/vol2-2/laurie.asp.

Mara K. 2011. IP and traditional expressions: An unnatural alliance? Intellectual Property Watch, January 5, 2011. www.ip-watch.org/2011/01/05/ip-traditional-culturalexpressions-an-unnatural-alliance/.

Merges PR. 2011. Justifying intellectual property. Harvard University Press, Cambridge, MA.

Munzer SR, Raustiala K. 2009. The uneasy case for intellectual property rights in traditional knowledge. Cardozo Arts Entertainment Law J 27: 37-97.

Prathapan KD, Rajan DP. 2011. Biodiversity access and benefit sharing: Weaving a rope of sand. Curr Sci 100: 290-293. 


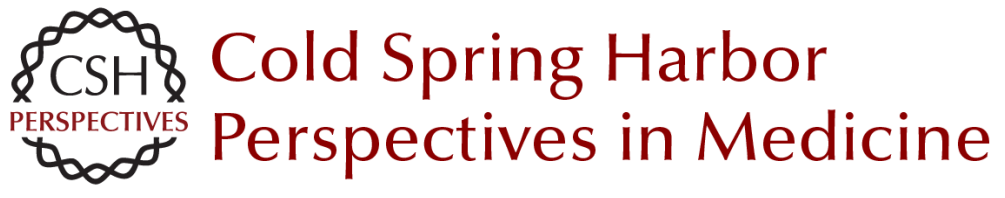

\section{Protecting Traditional Knowledge Related to Biological Resources: Is Scientific Research Going to Become More Bureaucratized?}

Prashant Reddy and Malathi Lakshmikumaran

Cold Spring Harb Perspect Med 2015; doi: 10.1101/cshperspect.a020974 originally published online June 22, 2015

\section{Subject Collection Intellectual Property in Molecular Medicine}

Patentability of Stem Cells in the United States Sarah E. Fendrick and Donald L. Zuhn, Jr.

Inventorship and Authorship

Antoinette F. Konski and Linda X. Wu

The Patentability of Stem Cells in Australia Jenny Petering and Prue Cowin

Impact of America Invents Act on Biotech

Intellectual Property

Amanda Murphy, Michael Stramiello, Jonathan Stroud, et al.

Introduction to Intellectual Property: A U.S.

Perspective

Amanda Murphy, Michael Stramiello, Stacy Lewis, et al.

The Role of Regulatory Agencies and Intellectual

Property: Part I

Kevin E. Noonan

Canada's Patented Medicines (Notice of

Compliance) Proceedings and Intellectual

Property

Henry Bian and Conor McCourt

Patentability of Genes: A European Union

Perspective

Paul Cole
The Impact of Myriad on the Future Development and Commercialization of DNA-Based Therapies and Diagnostics

Michele Wales and Eddie Cartier

Protecting Traditional Knowledge Related to

Biological Resources: Is Scientific Research

Going to Become More Bureaucratized?

Prashant Reddy and Malathi Lakshmikumaran

Protecting Trade Secrets in Canada Noel Courage and Janice Calzavara

Inherent Anticipation in the Pharmaceutical and

Biotechnology Industries

Michael Goldman, Georgia Evans and Andrew Zappia

The Role of Regulatory Agencies and Intellectual

Property: Part II Kevin E. Noonan

Baseball Bats and Chocolate Chip Cookies: The Judicial Treatment of DNA in the Myriad Genetics Litigation lan Binnie and Vanessa Park-Thompson

The Impact of Myriad and Mayo: Will

Advancements in the Biological Sciences Be

Spurred or Disincentivized? (Or Was Biotech

Patenting Not Complicated Enough?) Jennifer Gordon

Trade Secrets in Life Science and Pharmaceutical Companies

Tara Nealey, Ronald M. Daignault and Yu Cai

For additional articles in this collection, see http://perspectivesinmedicine.cshlp.org/cgi/collection/ 